\title{
Prevalence and Intensity of Infections of Ascaris lumbricoides and Trichuris trichiura and Associated Socio-demographic Variables in Four Rural Honduran Communities
}

\author{
HM Smith, RG DeKaminsky**, S Niwas*, RJ Soto***, PE Jolly/ ${ }^{+}$
}

\begin{abstract}
Department of Epidemiology and International Health, School of Public Health *Biostatistics Unit, Comprehensive Cancer Center, University of Alabama, 1665 University Boulevard, Ryals Building, Room 217, Birmingham, Alabama 35294-0022, USA **Dirección de Investigación Cientifica, Unidad de Investigación Cientifica,

Facultad de Ciencias Medicas ***Universidad Nacional Autonoma de Honduras, Tegucigalpa, Honduras
\end{abstract}

Between January and March 1998, a cross-sectional survey was carried out in four rural communities in Honduras, Central America. We examined the prevalence and intensity of Ascaris lumbricoides and Trichuris trichiura infections among 240 fecal specimens, and the association between selected socio-demographic variables and infection for 62 households. The overall prevalence of A. lumbricoides and T. trichiura was 45\% (95\% CI 39.0-51.9) and 38\% (95\% CI 31.8-44.4) respectively. The most intense infections for Ascaris and Trichuris were found in children aged 2-12 years old. By univariate analysis variables associated with infections of A. lumbricoides were: number of children 2-5 years old $(p=0.001)$, level of formal education of respondents $(p=0.01)$, reported site of defecation of children in households ( $p=0.02)$, households with children who had a recent history of diarrhea $(p=0.002)$, and the location of households $(p=0.03)$. Variables associated with both A. lumbricoides and T. trichiura infection included: number of children 6-14 years old ( $p=0.01, p=0.04$, respectively), ownership of a latrine ( $p=0.04, p=0.03$, respectively) and coinfection with either helminth ( $p=0.001, p=0.001$, respectively). By multivariate analysis the number of children 2-5 years living in the household, $(p=0.01$, odds ratio $(O R)=22.2)$, children with a recent history of diarrhea $(p=0.0, O R=39.8)$, and infection of household members with $\mathrm{T}$. trichiura $(p=0.02$, OR=16.0) were associated with A. lumbricoides infection. The number of children 6-14 years old in the household was associated with both $\mathrm{A}$. lumbricoides and $\mathrm{T}$. trichiura infection ( $p=0.04, p=0.01, O R=19.2$, OR $=5.2$, respectively).

Key words: intestinal helminths - Ascaris lumbricoides - Trichuris trichiura - prevalence - intensity risk factors - Honduras

Intestinal parasites remain a major health problem in many developing countries. The World Health Organization (WHO) estimated that there were 1000 million cases of ascariasis due to Ascaris lumbricoides, and 500 million cases of Trichuris trichiura infection worldwide (WHO 1987). In 1994, Chan et al. (1994c) estimated that worldwide there were 1471 million and 1048 million cases of A. lumbricoides and T. trichiura infections,

\footnotetext{
This study was supported by the Sparkman Center for International Public Health Education, University of Alabama at Birmingham School of Public Health, the Universidad Nacional Autonoma de Honduras, and the Escuela Agricola Panamericana, Honduras.

+Corresponding author. Fax: 205-975-3329. E-mail: jollyp@uab.edu

Received 31 August 2000

Accepted 4 October 2000
}

respectively. Clinically, A. lumbricoides can cause blockage of the intestine and $T$. trichiura has been associated with dysentery (Cooper et al. 1992). Both helminths have also been associated with stunted growth (Cooper \& Bundy 1988, Stephenson et al. 1989, 1993, Adams et al. 1994, Simeon et al. 1995, Hadju et al. 1996, 1997, Saldiva et al. 1999) and impaired cognitive functions in children (Nokes et al. 1992a, b, Oberhelman et al. 1998). Another common soil transmitted helminth that causes severe morbidity and is often found with A. lumbricoides and T. trichiura infections is hookworm (WHO 1987). However, hookworm infection will not be included in this research since the method used (Kato thick smear) for detecting eggs in the study was not suitable for recovery of hookworm eggs.

Countries in Central America, such as El Salvador, Guatemala, and Honduras, have a high prevalence of parasitic infections. A survey of intestinal parasites in children with diarrhea in El 
Salvador, demonstrated that $18 \%$ of the children were infected with $A$. lumbricoides and $31 \%$ with T. trichiura (Reinthaler et al. 1988). In Guatemala, $41 \%$ of the population in a rural village was infected with A. lumbricoides and $60 \%$ with $T$. trichiura (Anderson et al. 1993). Data from 14 public health laboratories in Honduras for 1991 showed A. lumbricoides infections in people of all ages ranging from $70 \%$ in Tocoa at the northern coast to $5 \%$ in Nacaome, near the Pacific coast. Percentages of individuals infected with $T$. trichiura were lower, ranging from $32 \%$ to $1 \%$ in the above mentioned areas (Kaminsky 1996a).

Although many studies regarding intestinal parasites focus on establishing the prevalence and intensity of these infections in different populations, fewer studies have examined the socio-cultural factors that affect transmission of intestinal helminths. Some studies have shown that the lack of education, lack of latrines, occurrence of diarrhea, lower socio-economic status, inadequate disposal of human excreta and the level of sanitation in households are related to parasitoses (Cooper \& Bundy 1988, Holland et al. 1988, Yasuf \& Hussain 1990, Rajeswari et al. 1994, Tshikuka et al. 1995, Ighogboja et al. 1997, Mahfouz et al. 1997, Pegelow et al. 1997, Gamboa et al. 1998). These reports coupled with the fact that there have been few surveys designed to determine associations between socio-cultural variables and intestinal helminth prevalence data prompted us to initiate this study in four rural Honduran communities.

In this study, we collaborated with Project UNIR (unite) based at the Panamerican Agricultural School (Escuela Agricola PanamericanaEAP), El Zamorano. The School is located in the Zamorano Valley, $40 \mathrm{~km}$ from Tegucigalpa, the nation's capital and was very willing and helpful in providing the necessary facilities and accommodations for one of us (HMS). Project UNIR is an organization at the EAP that was established in 1996. Its principal goals are both rural development and land conservation. We studied the prevalence and intensity of Ascaris and Trichuris infections in individuals of all ages in four communities under UNIR, and identified variables that have an important association with such infections.

\section{MATERIALS AND METHODS}

Study area and population - A cross-sectional survey was conducted between January and March 1998, in four rural communities in Honduras: El Llano, El Chaguite, Santa Ines, and El ChaguiteBelen. These communities were selected because they were part of an on-going nutritional study being conducted by students and staff under UNIR at the EAP and were accessible. El Llano, El
Chaguite, and Santa Ines are located in the municipality of San Antonio de Oriente. El ChaguiteBelen lies in the municipality of Maraita. These municipalities form part of the department of Francisco Morazan (Fig. 1). The estimated populations of El Llano, El Chaguite, Santa Ines and El Chaguite-Belen were 261, 437, 237 and 225 respectively. The four communities are located 40$60 \mathrm{~km}$ from Tegucigalpa, the nation's capital. The majority of the inhabitants were subsistence farmers and had limited access to major cities.

Collection of data - Approval for this study was obtained from the Institutional Review Board at the University of Alabama at Birmingham, and local institutions in Honduras. The EAP provided facilities, laboratory space and equipment. Prior to the beginning of the study, community meetings were held in public schools in the four communities. The study was discussed with the community members who were informed that their participation was voluntary. A pilot questionnaire was subsequently administered to two individuals from two separate households in Santa Ines and El Chaguite-Belen, respectively. Maps of each community were obtained from UNIR office files. Names of the heads-of-households were obtained from community members. Households to be visited were randomly selected using the listed names of the head-of-household. It is noteworthy that "household" may have been comprised of more than one dwelling unit. The criteria for participation were that participants were related to the headof-household, and/or considered themselves as members of the household. The entire household, except children less than 2 years old, was included in the study. Excluded from the study were individuals who did not live fulltime in the community being surveyed and households where individuals had completed the pilot questionnaire. The latter were excluded in order to minimize bias.

Personal interviews were conducted after obtaining the informed verbal consent of the caretaker. A pre-tested, standardized questionnaire was used to obtain information, such as, the number and ages of children in the household, level of education, sex, age of caretaker, whether someone in the household had passed A. lumbricoides, knowledge of how one acquires Ascaris, whether the household had a latrine, where the respondent and the children in the household defecated, whether the respondent and the children in the household used the latrine regularly, why not (if applicable), whether children in the household had had diarrhea recently, and how the respondent thought children acquired "worms". A preserved specimen of A. lumbricoides was used for demonstration purposes. A total of 62 caretakers, 14 


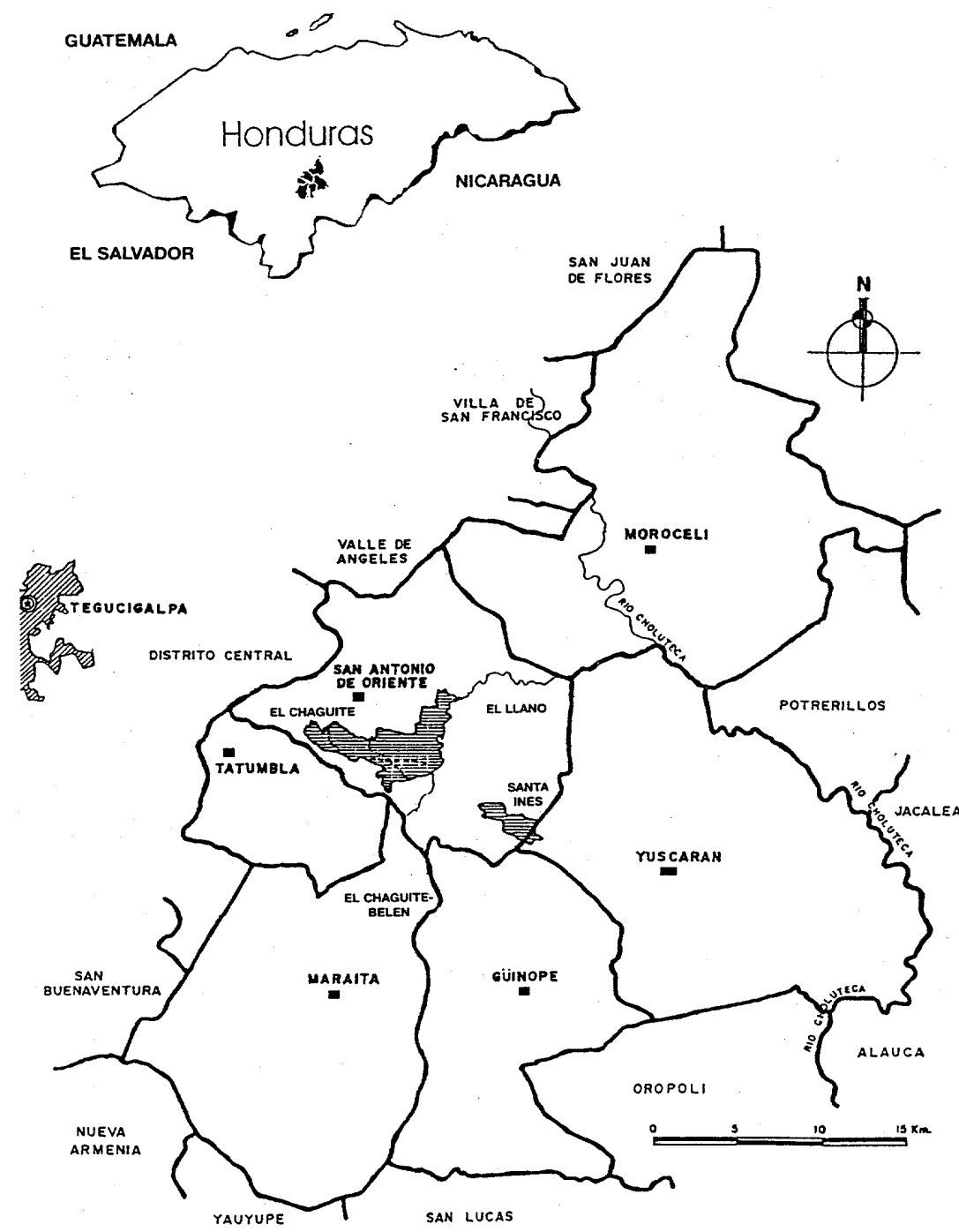

Fig. 1: map showing location of El Chaguite, El Chaguite-Belen, El Llano and Santa Ines, Department of Francisco Morazan, Honduras.

from El Chaguite, 14 from El Chaguite-Belen, 18 from El Llano and 16 from Santa Ines, were interviewed.

Collection and analysis of fecal specimens Following the questionnaire, specimen cups labeled with name, age, and gender were given to each individual in the household who wanted to participate in the study. The next morning the specimens were retrieved and taken to a laboratory at the EAP for analysis. Only one specimen was submitted per individual. A total of 240 specimens were collected from the four sites; 66 from El Chaguite, 44 from El Chaguite-Belen, 74 from El Llano, and 56 from Santa Ines. The Kato-Katz thick smear standardized to deliver $41.7 \mathrm{mg}$ of strained stool was used to diagnose A. lumbricoides and T. trichiura infections and estimate their intensity through egg counts (Kaminsky 1996b). Individuals were categorized as having light, moderate or heavy infections based on criteria set by WHO (1987). For $A$. lumbricoides an egg count of 0-4,999 eggs per gram (epg) of feces is regarded as a light infection and 5,000-50,000 epg, and >50,000 epg as moderate and heavy infections respectively. In $T$. trichiura infection the presence of 0-999 epg is regarded as a light infection, between 1,000-10,000 epg as a moderate infection and >10,000 epg as a heavy infection (WHO 1987).

Data analyses - Epi Info Version 6.0 software (CDC, Atlanta, GA) and SAS software (SAS Institute, Cary, NC) were used to analyze frequency, prevalence, intensity and associations. Socio-de- 
mographic variables were categorized into two or three groups. The chi-square or Fisher's exact test was calculated using the SAS software to assess the univariate association of the variables with the presence of $A$. lumbricoides and $T$. trichiura in each household. A multiple logistic regression model, using the SAS software, was employed to determine variables significantly associated with Ascaris infection. Only variables that were significantly associated with $A$. lumbricoides from the univariate model were included in the multiple logistic regression model. A stepwise selection method was employed to determine the variables significantly associated with A. lumbricoides infection. The fit of the final logistic regression model was assessed using the log likelihood ratio test and Akaike information criterion (AIC). Odds ratios and the corresponding standard errors were calculated using the variables significantly associated with A. lumbricoides infection. A similar analytical approach was performed to determine those variables significantly associated with $T$. trichiura infection.

\section{RESULTS}

Description of the study population - The mean age of respondents to the questionnaire was 39.4 years [standard deviation $(\mathrm{SD})=16.3$, median age $=35.5$ years] and more than $95 \%$ of respondents were females. The age of the 240 subjects sampled ranged from 2 to 84 years with a mean age of 20.6 years $(\mathrm{SD}=19.3$, median age $=11.0)$. Fifty-three percent of those sampled were female and $47 \%$ male. Seventy-one percent of respondents had some formal education; the majority $(51.6 \%)$ had some primary education (completed 1-6 years) and $19.4 \%$ had some years of secondary education (completed $7-12$ years).

Prevalence and intensity of A. lumbricoides and T. trichiura - The overall prevalence of $A$. lumbricoides and T. trichiura in these four communities was $45 \%$ (95\% CI 39.0-51.9) and 38\% (95\% CI 31.8-44.4), respectively (Table I). Over a quarter $(25.8 \%)$ of the 240 stool specimens examined had double infection of both $A$. lumbricoides and T. trichiura. Table I shows the differences in prevalence and intensity of Ascaris and Trichuris infection by age group and community. Overall, infections of Ascaris were mostly moderate and light, except in El Chaguite where there were heavy infections. There were primarily light infections of $T$. trichiura, except again in El Chaguite where moderate infections were observed. There were no heavy infections of $T$. trichiura.

El Llano had the lowest prevalence overall of both A. lumbricoides and T. trichiura and the least number of $T$. trichiura infections across all age groups. Twenty-two percent of the population surveyed in this community was infected with Ascaris and $11 \%$ were infected with Trichuris. Most infections, including one case of heavy infection and two cases of moderate infection with Ascaris, were found in children 2-4 years old and 5-12 years old. However, there were no infections of Trichuris in the 2-4 age group.

El Chaguite was the community with the highest prevalence of Ascaris and Trichuris; $82 \%$ of those surveyed had infections of Ascaris and $71 \%$ had infections of Trichuris. El Chaguite had much higher rates of infection in all age groups with $A$. lumbricoides and T. trichiura. Most infections of T. trichiura occurred in those 5-12 years old followed by individuals $>12$ years old.

The prevalence of Ascaris in Santa Ines and El Chaguite-Belen was $29 \%$ and $52 \%$, respectively. The prevalence of Trichuris in each of these communities was $30 \%$ and $43 \%$, respectively. In Santa Ines, individuals aged 2-4, had the highest frequency (40\%) of moderate Ascaris infection, while those aged 5-12 and >12 had substantial frequencies (close to $30 \%$ ) of both moderate and light infections. Individuals aged 5-12 years had the highest frequency (48\%) of light infections of $T$. trichiura. Twenty percent of those $>12$ years old had light infections of Trichuris. In El ChaguiteBelen the highest frequency of infection (moderate and light) of Ascaris and Trichuris occurred in those aged 5-12, followed by those aged $>12$. There was only one infection of Ascaris or Trichuris in children aged 2-4 in this community (Table I).

Fig. 2 shows the overall intensity of $A$. lumbricoides infections in all the communities. Children aged 2-4 had the heaviest infections while children aged 5 to 12 were most frequently infected with moderate and light infections compared to other age groups. Overall, there were more intense infections (heavy and/or moderate) of Ascaris than Trichuris in all age groups. Fig. 3 shows the overall intensity of T. trichiura infections in all the communities. Children aged 5 to 12 more frequently had moderate and light infections of Trichuris compared to other age groups. There were more light infections of Trichuris in children aged 5 to 12 than there were light infections of Ascaris in the same age group. Also, individuals $>12$ years were more frequently infected with light infections of Trichuris than they were with light infections of Ascaris.

Socio-demographic characteristics of household by infections of A. lumbricoides and T. trichiura - Univariate analysis was used to exam- 
TABLE I

Intensity of Ascaris lumbricoides and Trichuris trichiura by age in four rural Honduran communities

\begin{tabular}{|c|c|c|c|c|c|c|c|}
\hline \multirow[b]{2}{*}{$\begin{array}{l}\text { Community/ } \\
\text { age in years }(\mathrm{N})\end{array}$} & \multicolumn{4}{|c|}{ A. lumbricoides } & \multicolumn{3}{|c|}{ T. trichiura } \\
\hline & $\begin{array}{l}\text { Heavy } \\
N(\%)\end{array}$ & $\begin{array}{l}\text { Moderate } \\
\mathrm{N}(\%)\end{array}$ & $\begin{array}{l}\text { Light } \\
\text { N (\%) }\end{array}$ & $\begin{array}{c}\text { Total } \\
\text { infected } \\
(\%)\end{array}$ & $\begin{array}{l}\text { Moderate } \\
\mathrm{N}(\%)\end{array}$ & $\begin{array}{l}\text { Light } \\
\text { N (\%) }\end{array}$ & $\begin{array}{c}\text { Total } \\
\text { infected } \\
(\%)\end{array}$ \\
\hline \multicolumn{8}{|l|}{ El Llano $(\mathrm{N}=74)$} \\
\hline $2-4(12)$ & $1(8.3)$ & - & $4(33.3)$ & $5(42)$ & - & - & - \\
\hline $5-12(28)$ & - & $2(7.1)$ & $7(25.0)$ & $9(32)$ & - & $7(25.0)$ & $7(25)$ \\
\hline$>12(34)$ & - & - & $2(5.9)$ & $2(5.9)$ & - & $1(2.9)$ & $1(3)$ \\
\hline Total infected (\%) & & & & $16(22)$ & & & $8(11)$ \\
\hline \multicolumn{8}{|c|}{ El Chaguite $\quad(\mathrm{N}=66)$} \\
\hline $2-4(9)$ & $2(22.2)$ & $4(44.4)$ & $1(11.1)$ & $7(78)$ & - & $2(22.2)$ & $2(22)$ \\
\hline $5-12(28)$ & $8(28.6)$ & $14(50.0)$ & $4(14.3)$ & $26(93)$ & $6(21.4)$ & $18(64.3)$ & $24(86)$ \\
\hline$>12(29)$ & - & $10(34.5)$ & $11(37.9)$ & $21(73)$ & $2(6.9)$ & $19(65.5)$ & $21(72)$ \\
\hline Total infected (\%) & & & & $54(82)$ & & & $47(71)$ \\
\hline \multicolumn{8}{|c|}{ Santa Ines $(\mathrm{N}=56)$} \\
\hline $2-4(5)$ & - & $2(40.0)$ & - & $2(40)$ & - & $1(20.0)$ & $1(20)$ \\
\hline $5-12(21)$ & - & $2(9.5)$ & $4(19.0)$ & $6(29)$ & - & $10(48)$ & $10(48)$ \\
\hline$>12(30)$ & - & $3(10.0)$ & $5(16.7)$ & $8(27)$ & - & $6(20)$ & $6(20)$ \\
\hline Total infected (\%) & & & & $16(29)$ & & & $17(30)$ \\
\hline \multicolumn{8}{|c|}{ El Chaguite-Belen $\quad(\mathrm{N}=44)$} \\
\hline $2-4(4)$ & - & $1(25.0)$ & - & $1(25)$ & - & $1(25.0)$ & $1(25)$ \\
\hline $5-12(19)$ & - & $7(36.8)$ & $5(26.3)$ & $12(63)$ & $2(10.5)$ & $9(47.4)$ & $11(58)$ \\
\hline$>12(21)$ & - & $7(33.3)$ & $3(14.3)$ & $10(48)$ & & $7(33.3)$ & $7(33)$ \\
\hline Total infected (\%) & & & & $23(52)$ & & & $19(43)$ \\
\hline \multicolumn{8}{|c|}{ All communities $\quad(\mathrm{N}=240)$} \\
\hline $2-4(30)$ & $3(10)$ & $7(23)$ & $5(17)$ & $15(50)$ & - & $4(13)$ & $4(13)$ \\
\hline $5-12(96)$ & $8(8)$ & $25(26)$ & $20(21)$ & $53(55)$ & $8(8)$ & $44(46)$ & $52(54)$ \\
\hline$>12(114)$ & - & $20(17.5)$ & $21(18.4)$ & $41(35.9)$ & $2(1.8)$ & $33(28.9)$ & $35(30.7)$ \\
\hline Total & & & & $109(45)$ & & & $91(38)$ \\
\hline $95 \% \mathrm{CI}$ & & & & $39.0-51.9$ & & & $31.8-44.4$ \\
\hline
\end{tabular}

$\mathrm{N}$ : number; - $:$ none infected

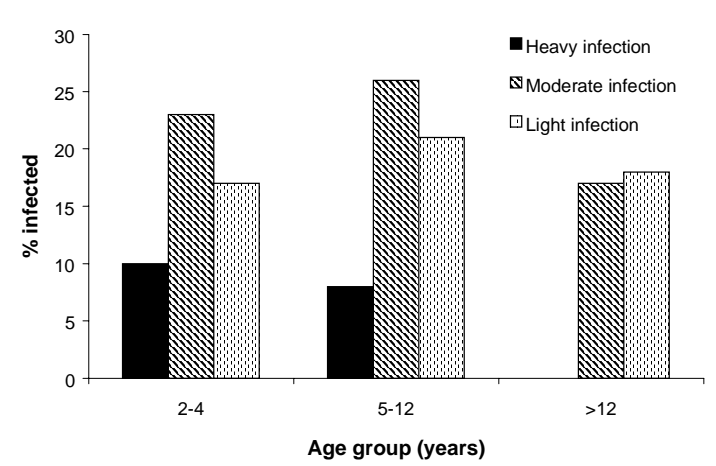

Fig. 2: intensity of Ascaris lumbricoides infection by age group categories in four rural communities in Honduras

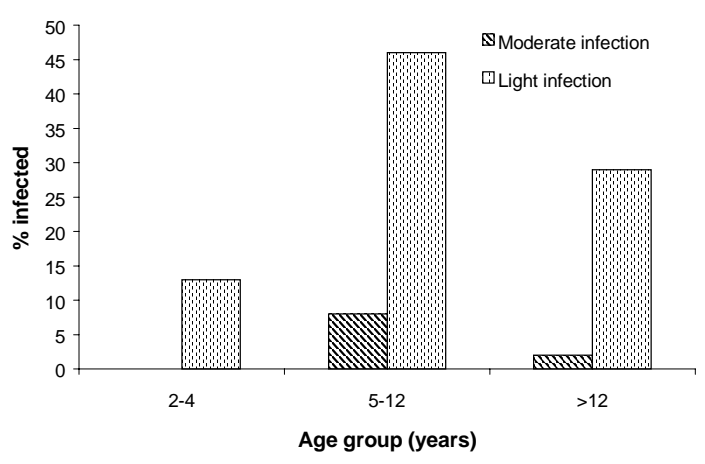

Fig. 3: intensity of Trichuris trichuria infection by age group categories in four rural communities in Honduras 
ine relationships between socio-demographic variables reported for the households and infections of A. lumbricoides and T. trichiura. Infections of A. lumbricoides by household associated with infections of T. trichiura and vice versa $(\mathrm{p}=0.001)$ (Tables II, III).

The four communities differed markedly from each other with respect to the prevalence of infections by both parasites, but only A. lumbricoides infection was significantly associated with infection by location of the household $(\mathrm{p}=0.03)$ (Table II). A higher percentage of households located in El Chaguite or El Chaguite-Belen, had members infected with A. lumbricoides than households in El Llano or Santa Ines. There were significant differences in prevalence between communities. When El Chaguite was compared univariately with the other three communities, in every instance, living in El Chaguite was significantly associated ( $\mathrm{p}<0.01$ ) with infections of $A$. lumbricoides or $T$. trichiura.

There was an association between the number of children 2 to 5 years old and the number of children 6-14 years old living in a household, and infection by $A$. lumbricoides in members of the household ( $\mathrm{p}=0.001, \mathrm{p}=0.001$, respectively) (Table

TABLE II

Univariate analysis: characteristics of households and their association with Ascaris lumbricoides infection

\begin{tabular}{|c|c|c|c|}
\hline \multirow[b]{2}{*}{ Variables } & \multicolumn{2}{|c|}{ Distribution of households by A. lumbricoides infection } & \multirow[b]{2}{*}{$\mathrm{p}^{- \text {value }}{ }^{a}$} \\
\hline & $\begin{array}{l}\text { Positive } \\
\text { No. }(\%)\end{array}$ & $\begin{array}{l}\text { Negative } \\
\text { No. }(\%) \\
\end{array}$ & \\
\hline $\begin{array}{l}\text { Households with members infe } \\
\text { Trichuris trichiura }\end{array}$ & & & \\
\hline $\begin{array}{l}\text { Yes } \\
\text { No }\end{array}$ & $\begin{array}{c}29(78.4) \\
9(36)\end{array}$ & $\begin{array}{l}8(21.6) \\
16(64)\end{array}$ & 0.001 \\
\hline $\begin{array}{l}\text { Location of household } \\
\text { El Llano } \\
\text { El Chaguite } \\
\text { Santa Ines } \\
\text { El Chaguite-Belen }\end{array}$ & $\begin{aligned} 9 & (50) \\
13 & (92.9) \\
7 & (43.8) \\
9 & (64.3)\end{aligned}$ & $\begin{array}{l}9(50) \\
1(7.1) \\
9(56.2) \\
5(35.7)\end{array}$ & 0.03 \\
\hline $\begin{array}{l}\text { No. of children } 2-5 \text { years old li } \\
\text { None } \\
1-2 \text { children } \\
3-10 \text { children }\end{array}$ & $\begin{array}{l}10(37) \\
26(81.2) \\
2(66.7)\end{array}$ & $\begin{array}{l}17(63) \\
6(18.8) \\
1(33.3)\end{array}$ & 0.001 \\
\hline $\begin{array}{l}\text { No. of children } 6-14 \text { years old } \\
\text { None } \\
1-2 \text { children } \\
3-10 \text { children }\end{array}$ & $\begin{array}{l}4(23.5) \\
16(64) \\
18(90)\end{array}$ & $\begin{array}{c}13(76.5) \\
9(36) \\
2(10)\end{array}$ & 0.001 \\
\hline $\begin{array}{l}\text { Level of formal education of re } \\
\text { None } \\
\text { Primary } \\
\text { Secondary }\end{array}$ & $\begin{array}{c}12(66.7) \\
23(71.9) \\
3(25)\end{array}$ & $\begin{array}{l}6(33.3) \\
9(28.1) \\
9(75)\end{array}$ & 0.01 \\
\hline $\begin{array}{l}\text { Reported site of defecation of } \mathrm{r} \\
\text { Latrine } \\
\text { Other (besides latrine) }\end{array}$ & $\begin{array}{l}22(51.2) \\
16(84.2)\end{array}$ & $\begin{array}{r}21(48.8) \\
3(15.8)\end{array}$ & 0.01 \\
\hline $\begin{array}{l}\text { Reported site of defecation of } \mathrm{c} \\
\text { Latrine } \\
\text { Other (besides latrine) }\end{array}$ & $\begin{array}{l}12(52.2) \\
25(83.3)\end{array}$ & $\begin{array}{r}11(47.8) \\
5(16.7)\end{array}$ & 0.02 \\
\hline $\begin{array}{l}\text { Ownership of latrine by househ } \\
\text { Yes } \\
\text { No }\end{array}$ & $\begin{array}{l}31(56.4) \\
7(100)\end{array}$ & $\begin{array}{l}24(43.6) \\
0(0)\end{array}$ & 0.04 \\
\hline $\begin{array}{l}\text { Children reported in household } \\
\text { history of diarrhea } \\
\text { Yes } \\
\text { No }\end{array}$ & $\begin{array}{l}19(95) \\
18(52.9)\end{array}$ & $\begin{array}{c}1(5) \\
16(47.1)\end{array}$ & 0.002 \\
\hline
\end{tabular}

$a$ : based on Chi square or Fisher's exact Test (2-sided) 
II). Households with children in these age groups had a greater frequency of Ascaris infection compared to households with no children in these age groups (Table II). Similarly, the number of children 6-14 years old in the household was also associated with infections of $T$. trichiura $(\mathrm{p}=0.01)$ (Table III). Households with children in this age group had a greater frequency of Trichuris infections than those households with no children in the age group.

Education was associated with $A$. lumbricoides infection within households $(\mathrm{p}=0.01)$ (Table II). A lower proportion (25\%) of family members was infected with $A$. lumbricoides in households where the respondent had a secondary education than in households where the respondent had no formal education (66.7\%).

Gender was examined as a possible variable associated with parasitoses. Approximately $45 \%$ of males and $45 \%$ of females of all ages surveyed were infected with A. lumbricoides. Approximately $41 \%$ of males and $35 \%$ of females of all ages were positive for infections with $T$. trichiura. There was no significant difference with respect to gender regarding infection with either Ascaris $(\mathrm{p}=0.97)$ or Trichuris $(\mathrm{p}=0.35)$ in the population surveyed. Also, there was no significant difference between gender with reference to intensity for Ascaris $(\mathrm{p}=0.64)$ or Trichuris $(\mathrm{p}=0.20)$ infections.

Associations between sanitary practices and infections of Ascaris or Trichuris by household was also examined. In this respect, certain variables such as lack of a latrine $(\mathrm{p}=0.04, \mathrm{p}=0.03)$
(Tables II, III), respondents defecating in a site other than the latrine $(\mathrm{p}=0.01, \mathrm{p}=0.04)$ (Tables II, III), children defecating in a site other than the latrine $(\mathrm{p}=0.02)$ (Table II), and children with a recent history of diarrrhea $(\mathrm{p}=0.002)$ (Table II) were associated with infections of either A. lumbricoides or $T$. trichiura respectively. In each case, households that did not own a latrine, or households where respondents and children did not always use the latrine for defecation, or where children were reported with diarrhea, had a higher percentage of members with infections of either helminth.

The most common reason given by respondents who did not always use the latrine for defecation, was that the family did not own one (31.6\%). Other common reasons given were that the latrine was broken $(26.3 \%)$ or that it was too far $(21.1 \%)$. Twenty-one percent of respondents had reasons other than those given above. The most common reasons given by respondents for children not always using the latrine was that the children did not know how to use it because they were too young $(30 \%)$, that the latrine was too far $(20 \%)$, and that the household did not own one (20\%). Another $16.7 \%$ said that the latrine was broken, and $13.3 \%$ indicated other reasons.

Although most individuals $(73.7 \%)$ did not know how someone could become infected with Ascaris, when specifically asked and shown the preserved specimen of Ascaris, $34.4 \%$ recalled that someone in the household had passed a worm at some time. The answers respondents gave to the question of how children became infected with

TABLE III

Univariate analysis: characteristics of households and their association with Trichuris trichiura infection

\begin{tabular}{|c|c|c|c|}
\hline \multirow[b]{2}{*}{ Variables } & \multicolumn{2}{|c|}{ Distribution of households by $T$. trichiura infection } & \multirow[b]{2}{*}{$\mathrm{p}^{- \text {value }^{a}}$} \\
\hline & $\begin{array}{l}\text { Positive } \\
\text { No. }(\%)\end{array}$ & $\begin{array}{l}\text { Negative } \\
\text { No. }(\%) \\
\end{array}$ & \\
\hline \multicolumn{4}{|c|}{ No. of children 6-14 years old living in household } \\
\hline None & $5(29.4)$ & $12(70.6)$ & 0.01 \\
\hline 1-2 children & $17(68)$ & $8(32)$ & \\
\hline 3-10 children & $15(75)$ & $5(25)$ & \\
\hline \multicolumn{4}{|c|}{ Reported site of defecation of respondents } \\
\hline Latrine & $22(51.2)$ & $21(48.8)$ & 0.04 \\
\hline Other & $15(79)$ & $4(21)$ & \\
\hline \multicolumn{4}{|c|}{ Ownership of latrine by household } \\
\hline Yes & $30(54.5)$ & $25(45.5)$ & 0.03 \\
\hline No & $7(100)$ & $0(0)$ & \\
\hline \multicolumn{4}{|c|}{ Households with members infected with } \\
\hline \multicolumn{4}{|c|}{ Ascaris lumbricoides } \\
\hline Yes & $29(76.3)$ & $9(23.7)$ & 0.001 \\
\hline No & $8(33.3)$ & $16(66.7)$ & \\
\hline
\end{tabular}

$a$ : based on chi-square or Fisher's exact test (2-sided) 
worms in general varied, but most (40.3\%) thought that "dirty hands or filth" was the cause. However, over a third of respondents (33.9\%) did not know how children acquired worms. The remainder $(25.9 \%)$ thought that water, candy, milk, eating bad food, etc. caused worms in children.

Multivariate analysis of variables associated with infections of A. lumbricoides and T. trichiura - Multivariate analysis was performed on all the variables with $p$-value of 0.05 or less by univariate analysis for both A. lumbricoides and T. trichiura, in order to eliminate confounding variables. Multivariate analysis identified the following variables as those statistically associated with infections of A. lumbricoides: number of children aged $2-5$ or 6-14 living in the household $(\mathrm{p}=0.01$ and $\mathrm{p}=0.04$, respectively), report of recent history of diarrhea in children in the household $(\mathrm{p}=0.01)$ and members of the household coinfected with T. trichiura $(\mathrm{p}=0.02)$. The only variable that was associated with $T$. trichiura infection was the number of children 6 to 14 years old living in the household $(\mathrm{p}=0.01)$ (Table IV).

\section{DISCUSSION}

A. lumbricoides and $T$. trichiura are highly prevalent in the communities studied in Honduras and the levels of infection are indicative of major problems in basic hygiene and sanitation. This survey found that children aged 5 to 12 years had a higher percentage of A. lumbricoides and $T$. trichiura infections than individuals in the other age groups. Children aged 2 to 12 years more frequently had infections of greater intensity than individuals older than 12 . Surveys completed in communities in other countries have shown that the prevalence of Ascaris drops in people older than 15 years (Bundy et al. 1987, Reinthaler et al. 1988, Hasegawa et al. 1992, Upatham et al.1992, Mangali et al. 1994). However, the prevalence of Trichuris does not drop off in adulthood (Bundy et al. 1987). In this study almost $25 \%$ of individuals $>12$ years had light infections of Trichuris. Other studies have shown peak intensity of Trichuris infection in individuals aged 10 to 29 (Anderson et al.1993) indicating that Trichuris may be a more chronic infection than Ascaris.

In this survey, individuals with the heaviest infections were concentrated in certain communities and in certain households in these communities. Often a minority of a population will produce large amounts of eggs indicating heavy infection, while the majority will have light infection and produce very few eggs (Palmer \& Bundy 1995). There is also a familial aggregation and predisposition to Ascaris and Trichuris infections (Chan et al. 1994a), which does not appear to be genetically determined but may be more strongly determined by environmental and behavioral factors (Chan et al. 1994b).

Over a quarter of this population was co-infected and the association of double infection was significant. Other studies have found that there is a positive association between $A$. lumbricoides and T. trichiura infections (Udonsi et al. 1996). Kightlinger et al. (1995) and Needham et al. (1998) have found a dual species intensity correlation for A. lumbricoides and T. trichiura infections; high intensity infections of A. lumbricoides were associated with high intensity infections of $T$. trichiura. The reasons for this are unclear, but it may be explained by the similar route of infection, the fecaloral, for both parasites.

Gender did not influence the likelihood of infection with either parasite in this population. Magambo et al. (1998) found that the infection rate of several intestinal pathogens including Trichuris was higher in males compared to females in Sudan, however, it was not reported if this difference was statistically significant. An epidemiological study from Madagascar found that girls had a significantly higher prevalence and intensity of ascariasis (Kightlinger et al. 1995) while another study from Guatemala did not find any gender differences with respect to parasitoses (Anderson et al. 1993). These results may indicate that gender may or may not play a role in parasitoses, depending on the region and other environmental or behavioral factors.

In places where sanitation is extremely poor, and a high prevalence of helminthic infection is suspected, a questionnaire can become an important tool because it may help to highlight certain practices or beliefs that are associated with parasite transmission. We compared questionnaire data with laboratory data. The relatively small sample of 62 households to which the questionnaires were administered is a limitation to the study. Many variables that were significant by univariate analysis did not sustain their significance after adjusting for other covariates in the multivariate analysis. In the univariate analysis, we evaluated the association of multiple covariates with $A$. lumbricoides and T. trichuria. We are aware that the multiple testing of these covariates can inflate the overall significance level. However, some of the significant associations which were observed by univariate analysis, have also been observed in other parasite studies conducted in other countries and deserve mentioning.

For example, we observed an association between the level of education of the respondent and the percent of household with members infected with A. lumbricoides. Some studies have noted 
that infection with $A$. lumbricoides occurs more frequently in the children of mothers with the least formal education (Holland et al. 1988, Tshikuka et al. 1995). We also found an association between latrine ownership and defecation site with helminth infection. Improper disposal of human waste has been associated with infections of intestinal helminths in other countries (Mahfouz et al. 1997). Studies have shown that children living in homes without latrines have a higher prevalence of Ascaris and Trichuris, than those living in homes with latrines, and the introduction of pit latrines can help lower the prevalence of diarrheal diseases (Hoque et al.1996, Pegelow et al. 1997).

The community in which the households were located was associated with infection by $A$. lumbricoides but not $T$. trichiura. Although we are not certain of the reason for this association, we observed that many homes in El Llano and Santa Ines had piped water in the front yards, unlike the homes in El Chaguite and El Chaguite-Belen where the most and heaviest infections were observed. In the latter two communities household members frequently had to walk long distances to get water. Although we did not compile information regarding the availability of water in these communities, government documents indicate that $32 \%$ of the households in the municipality of San Antonio de
Oriente and $49 \%$ of households in the municipality of Maraita lack potable water (Secretaria de Gobernacion y Justicia de Honduras 1995). The availability of water may influence a household's sanitation level in general (VanDerslice \& Briscoe 1995, Esrey 1996, Hoque et al. 1996, Semenza et al. 1998).

Varying levels of sanitation may have also influenced the prevalence of infection by community. An intestinal helminth study done in the Brazilian Amazon found that differences in prevalence between the districts surveyed may have been due to the degree of hygienic practices in each area. Some people used the latrine more than others (Eve et al. 1998).

Multivariate analysis was performed in order to control for possible confounding effects of other study variables. The association between the number of children aged 2-5 years or 6-14 years living in the household and parasite infection may have occurred because children less than 15 years old constitute the age group that is most frequently infected by Ascaris and Trichuris (Bundy et al. 1987, Reinthaler et al. 1988, Hasegawa et al. 1992, Upatham et al. 1992, Mangali et al. 1994). The association of $A$. lumbricoides with diarrhea could be due to general uncleanliness within the household, or other confounders not controlled for, since

TABLE IV

Multiple logistic regression analysis with coefficients presented as odds ratio for associations with Ascaris lumbricoides or Trichuris trichiura infection

\begin{tabular}{|c|c|c|c|}
\hline Variable & $\beta \pm \mathrm{SE}^{a}$ & $\mathrm{OR}^{b}$ & $\mathrm{p}$-value \\
\hline \multicolumn{4}{|l|}{ Infection with $A$. lumbricoides } \\
\hline $\begin{array}{l}\text { No. of children } 2-5 \text { years old living in household } \\
\text { None } \\
\geq 1 \text { Child }\end{array}$ & $\begin{array}{c}0 \\
3.1 \pm 1.2\end{array}$ & $\begin{array}{l}1.00 \\
22.2\end{array}$ & 0.01 \\
\hline $\begin{array}{l}\text { No. of children } 6-14 \text { years old living in household } \\
\text { None } \\
\geq 1 \text { Child }\end{array}$ & $\begin{array}{c}0 \\
2.9 \pm 1.4\end{array}$ & $\begin{array}{l}1.00 \\
19.2\end{array}$ & 0.04 \\
\hline $\begin{array}{l}\text { Report of recent history of diarrhea in children } \\
\text { in the household } \\
\text { No } \\
\text { Yes }\end{array}$ & $\begin{array}{c}0 \\
3.7 \pm 1.5\end{array}$ & $\begin{array}{l}1.00 \\
39.8\end{array}$ & 0.01 \\
\hline $\begin{array}{l}\text { Members of household also infected with } \\
\text { Trichuris trichiura } \\
\text { No } \\
\text { Yes }\end{array}$ & $\begin{array}{c}0 \\
2.8 \pm 1.1\end{array}$ & $\begin{array}{l}1.00 \\
16.0\end{array}$ & 0.02 \\
\hline \multicolumn{4}{|l|}{ Infection with $T$. trichiura } \\
\hline $\begin{array}{l}\text { Children 6-14 years old living in household } \\
\text { None } \\
\geq 1 \text { Child }\end{array}$ & $\begin{array}{c}0 \\
1.6 \pm .63\end{array}$ & $\begin{array}{l}1.00 \\
5.2\end{array}$ & 0.01 \\
\hline
\end{tabular}

$a$ : regression coefficient \pm standard error; $b$ : odds ratio 
diarrhea is not normally associated with Ascaris infection (Genta 1993). That is, the conditions that allow A. lumbricoides to thrive, are also ideal for the existence of other enteric pathogens that cause diarrhea. In this study we did not look for protozoan or other enteric pathogens, nor was there a clinical definition given for "diarrhea".

As a part of this study, we asked respondents questions about their sanitary practices and the reasons behind those practices. In so doing we hoped to shed some light on reasons for poor sanitation in these communities. We also asked questions regarding knowledge of parasites in general, using A. lumbricoides as a model, because it is an easy helminth to demonstrate and was widely recognized in this population. We found that most people knew of someone in the household who had passed an Ascaris worm before, but that the majority did not know the etiology of the infection. This may indicate that although specific knowledge of how the worm was transmitted was low, awareness of Ascaris in the community was quite high, and parasite transmission may be an area where an educational intervention might have an impact.

Many individuals did have a response ready when asked how children acquired parasites, and the most common answer was that dirty hands or filth was responsible for "worms", where "worms" meant Ascaris. In a study from Bangladesh, women were asked a similar question and approximately $28 \%$ of respondents answered that "unclean hands" was the cause. A variety of other answers related to cleanliness were also given. A more common answer in Bangladesh (37\%) was that sweets gave children worms (Rousham 1994). A similar study from Nepal showed that $38.46 \%$ of respondents knew that soil was involved with transmission, but $21.15 \%$ attributed worms to the consumption of sweets (Williams-Blangero et al. 1998). In this study, only $9.7 \%$ of respondents cited candy among other things as being the source of infection.

The results of this study indicate that there are certain factors observed in helminth transmission, which are common to developing countries in the tropics, such as, general contamination of the living environment and larger numbers of young children living in households. Hence, knowledge of these factors may help reduce costs of studies for policy formulation, and facilitate implementation of public health interventions designed to reduce the incidence of helminth infections in developing countries with similar environmental conditions and sanitary practices. Community-based mass chemotherapy on a regular basis can meet shortterm objectives of intestinal helminth reduction, and is the most cost-effective method (Mascle-Tay- lor et al. 1999). Health promotion education, the adoption of hygienic practices, and school-based deworming programs can have long-term benefits and have proven effective in other countries (Holland et al. 1996, Stolzfus et al. 1997, Mascle-Taylor et al. 1999).

\section{ACKNOWLEDGEMENTS}

To Eduardo Aguilar and Suyapa Meyer for all their help at the Escuela Agricola Panamericana. To the staff and students of the Project UNIR, and Dr Luis Castellanos at the Pan American Health Organization for his suggestions. To Dr Ed Cupp, Dr Richard and Ms Marie Hudspeth, Dr Curtis Jolly, Dr Jerold Theis and Dr Heidi Weiss for reviewing the manuscript. To the people of El Llano, El Chaguite, Santa Ines, and El Chaguite-Belen for their cooperation in this survey.

\section{REFERENCES}

Adams EJ, Stephenson LS, Latham MC, Kinoti SN 1994. Physical activity and growth in Kenyan school children with hookworm, Trichuris trichiura and Ascaris lumbricoides infections are improved after treatment with albendazole. J Nutr 124: 1199-1206.

Anderson TJC, Zizza CA, Leche GM, Scott ME, Solomons NE 1993. The distribution of intestinal helminth infections in a rural village in Guatemala. Mem Inst Oswaldo Cruz 88: 53-65.

Bundy DAP, Cooper ES, Thompson DE, Didier JM, Simmons I 1987. Epidemiology and population dynamics of Ascaris lumbricoides and Trichuris trichiura infection in the same community. Trans $R$ Soc Trop Med Hyg 81: 987-993.

Chan L, Bundy DA, Kan SP 1994a. Aggregation and predisposition to Ascaris lumbricoides and Trichuris trichiura at the familial level. Trans $R$ Soc Trop Med Hyg 88: 46-48.

Chan L, Bundy DA, Kan SP 1994b. Genetic relatedness as a determinant of predisposition to Ascaris lumbricoides and Trichuris trichiura infection. Parasitology 108: 77-80.

Chan MS, Medley GF, Jamison D, Bundy DAP 1994c. The evaluation of potential global mortality attributable to intestinal nematode infections. Parasitology 109: 373-387.

Cooper ES, Bundy DAP 1988. Trichuris is not trivial. Parasitol Today 4: 301-306.

Cooper ES, Whyte-Alleng CAM, Finzi-Smith JS, MacDonald TT 1992. Intestinal nematode infections in children: the pathophysiologic price paid. Parasitology 104: S91-S93.

Esrey S 1996. Water, waste, and well-being: a multicountry study. Am J Epidemiol 143: 608-623.

Eve E, Ferraz E, Thatcher VE 1998. Parasitic infections in villagers from three districts of the Brazilian Amazon. Ann Trop Med Parasitol 92: 79-87.

Gamboa MI, Basualdo JA, Kozubsky L, Costas E, Cuento Rua E, Lahitte HB 1998. Prevalence of intestinal parasitosis within three populations in $\mathrm{La}$ Plata, Argentina. Eur J Epidemiol 14: 55-61.

Genta RM 1993. Diarrhea in helminthic infections. Clin Infect Dis 16: S122-129. 
Hadju V, Abadi K, Stephenson LS 1997. Relationships between soil-transmitted helminthiases and growth in urban slum schoolchildren in Ujung Pandang, Indonesia. Int J Food Sci Nutr 48: 85-93.

Hadju V, Stephenson LS, Abadi K, Mohammed HO, Bowman DD, Parker RS 1996. Improvements in apetite and growth in helminth-infected schoolboys three and seven weeks after a single dose of pyrantel pamoate. Parasitology 113: 497-504.

Hasegawa H, Miyagi I, Toma T, Kamimura K, Nainggolan IJJ, Tumewu-Wagei M, MandagiWaworuntu HG, Kapojos FX, Runtuwene J, PaathRuntupalit CS 1992. Intestinal parasitic infections in Likupang, North Sulawesi, Indonesia. Southeast Asian J Trop Med Public Health 23: 219-227.

Holland CV, Asaolu SO, Crompton DWT, Whitehead RR, Coombs I 1996. Targeted anthelminthic treatment of school children: effect of frequency of application on the intensity of Ascaris lumbricoides infection in children from rural Nigerian villages. Parasitology 113: 87-95.

Holland CV, Taren DL, Crompton DWT, Nesheim MC, Sanjur D, Barbeau I, Tucker K, Tiffany J, Rivera G 1988. Intestinal helminthiases in relation to the socioeconomic environment of Panamanian children. Soc Sci Med 26: 209-213.

Hoque BA, Juncker T, Sack RB, Ali M, Aziz KMA 1996. Sustainability of a water, sanitation and hygiene education project in rural Bangladesh. Bull WHO 74: 431-437.

Ighogboja IS, Ikeh EI 1997. Parasitic agents in childhood diarrhoea and malnutrition. West Afr J Med 16: 36-39.

Kaminsky R 1996a. El Parasitismo en Honduras, Serie de diagnosticos No.14: PAHO, WHO, Universidad Nacional Autonoma de Honduras, Honduras.

Kaminsky R 1996b. Manual de Parasitologia. Tecnicas para Laboratorios de Atencion Primaria de Salud, Organizacion Panamericana de la Salud, Honduras.

Kightlinger LK, Seed JR, Kightlinger MB 1995. Ascaris lumbricoides intensity in relation to environmental, socioeconomic, and behavioral determinants of exposure to infection in children from southeast Madagascar. J Parasitol 81: 480-484.

Magambo JK, Zeyhle E, Wachira TM 1998. Prevalence of intestinal parasites among children in Southern Sudan. East Afr Med J 75: 288-290.

Mahfouz AAR, El-Morshedy H, Farghaly A, Khalil A 1997. Ecological determinants of intestinal parasitic infections among pre-school children in an urban squatter settlement of Egypt. J Trop Pediatr 43: 341344.

Mangali A, Sasabone P, Abadi K, Hasegawa H, Toma T, Kamimura K, Hasan M, Miyagi I, Mogi M 1994. Prevalence of intestinal helminthic infections in Kao District, North Halmahera, Indonesia. Southeast Asian J Trop Med Public Health 25: 737-744.

Mascle-Taylor CG, Alam M, Montanari RM, Karim R, Ahmed T, Karim E, Akhtar S 1999. A study of the cost-effectiveness of selective health interventions for the control of intestinal parasites in rural Bangladesh. J Parasitol 85: 6-11.
Needham C, Hoang TK, Nguyen VH, Cong LD, Michael E, Drake L, Hall A, Bundy DAP 1998. Epidemiology of soil-transmitted nematode infections in Ha Nam Province, Vietnam. Trop Med Int Health 3: 904-912.

Nokes C, Grantham-McGregor SM, Sawyer AW, Cooper ES, Bundy DAP 1992a. Parasitic helminth infection and cognitive function in school children. Proc R Soc Lond Biol Sci 247: 77-81.

Nokes C, Grantham-McGregor SM, Sawyer AW, Cooper ES, Robinson BA, Bundy DA 1992b. Moderate to heavy infections of $T$. trichiura affect cognitive function in Jamaican school children. Parasitology 104: 539-547.

Oberhelman RA, Guerrero ES, Fernandez ML, Silio M, Mercado D, Comiskey N, Ihenacho G, Mera R 1998. Correlations between intestinal parasitosis, physical growth, and psychomotor development among infants and children from rural Nicaragua. Am J Trop Med Hyg 58: 470-475.

Palmer DR, Bundy DA 1995. Epidemiology of human hookworm and Ascaris lumbricoides infestations in rural Gambia. East Afr Med J 72: 527-530.

Pegelow K, Gross R, Pietrzik K, Lukito W, Richards AL, Fryauff DJ 1997. Parasitological and nutritional situation of school children in the Sukaraja district, West Java, Indonesia. Southeast Asian J Trop Med Public Health 28: 173-190.

Rajeswari B, Sinniah B, Hussein H 1994. Socio-economic factors associated with intestinal parasites among children living in Gombak, Malaysia. Asia Pac J Public Health 7: 21-25.

Reinthaler FF, Linck G, Klem G, Mascher F, Sixl W 1988. Intestinal parasites in children with diarrhea in El Salvador. Geo Med 18: 175-180.

Rousham EK 1994. Perceptions and treatment of intestinal worms in rural Bangladesh: local differences in knowledge and behaviour. Soc Sci Med 39: 10631068.

Saldiva SR, Silveira AS, Philippi ST, Torres DM, Mangini AC, de Souza Dias RM, da Silva RM, Buratini MN, Massad E 1999. Ascaris-Trichuris association and malnutrition in Brazilian children. Paediatr Perinat Epidemiol 13: 89-98.

Secretaria de Gobernacion y Justicia de Honduras 1995. Categorizacion Municipal segun Indicadores de Necesidades Basicas Insatisfechas. Pacto por la Infancia, Honduras.

Semenza JC, Roberts L, Henderson A, Bogan J, Rubin $\mathrm{CH}$ 1998. Water distribution system and diarrheal disease transmission: a case study in Uzbekistan. Am J Trop Med Hyg 59: 941-946.

Simeon DT, Grantham-McGregor SM, Callender JE, Wong MS 1995. Treatment of Trichuris trichiura infections improves growth, spelling scores and school attendance in some children. J Nutr 125: 1875-1883.

Stephenson LS, Latham MC, Adams EJ, Kinoti SN, Pertet A 1993. Physical fitness, growth and appetite of Kenyan school boys with hookworm, Trichuris trichiura, and Ascaris lumbricoides infections are improved four months after a single dose of albendazole. J Nutr 123: 1036-1046. 
Stephenson LS, Latham MC, Kurz KM, Kinoti SN, Brigham H 1989. Treatment with a single dose of albendazole improves growth of Kenyan schoolchildren with hookworm, Trichuris trichiura and Ascaris lumbricoides infections. Am J Trop Med Hyg 41: 78-87.

Stoltzfus RJ, Albonico M, Tielsch JM, Chwaya HM, Savioli L 1997. School-based deworming programs yield small improvement in growth of Zanzibari school children after one year. J Nutr 127: 2187-2193

Tshikuka JG, Scott ME, Gray-Donald K 1995. Ascaris lumbricoides infection and environmental risk factors in an urban African setting. Ann Trop Med Parasitol 89: 505-514.

Udonsi JK, Behnke JM, Glibert FS 1996. Analysis of the prevalence of infection and associations between human gastrointestinal nematodes among different ages classes living in urban and suburban communities of Port Harcourt, Nigeria. J Helminthol 70:
74-84.

Upatham KS, Viyanant V, Brockelman WY, Kurathong S, Ardsungnoen P, Chindaphol U 1992. Predisposition to reinfection by intestinal helminths after chemotherapy in South Thailand. Int J Parasitol 22: 801-806.

VanDerslice J, Briscoe J 1995. Environmental interventions in developing countries: interactions and their implications. Am J Epidemiol 141: 135-144.

Williams-Blangero S, Subedi J, Upadhayay RP, Manral DB, Khadka K, Jirel S, Robinson ES, Blangero J 1998. Attitudes towards helminthic infection in the Jirel population of Eastern Nepal. Soc Sci Med 47: 371-379.

WHO-World Health Organization 1987. Prevention and control of intestinal parasitic infections. WHO Tech Rep 749: 1-86

Yasuf M, Hussain AMZ 1990. Sanitation in rural communities in Bangladesh. Bull WHO 68: 619-624. 